\title{
Copper doped zeolite composite for antimicrobial activity and heavy metal removal from waste water
}

\author{
Feleke Terefe Fanta ${ }^{1}$, Amare Aregahegn Dubale ${ }^{1 *}$, Dawit Firemichael Bebizuh ${ }^{1}$ \\ and Minaleshewa Atlabachew $2,3^{*}$ (1)
}

\begin{abstract}
Background: The existence of heavy metals and coliform bacteria contaminants in aquatic system of Akaki river basin, a sub city of Addis Ababa, Ethiopia has become a public concern as human population increases and land development continues. Hence, it is the right time to design treatment technologies that can handle multiple pollutants.

Results: In this study, we prepared a synthetic zeolites and copper doped zeolite composite adsorbents as cost effective and simple approach to simultaneously remove heavy metals and total coliforms from wastewater of Akaki river. The synthesized copper-zeolite X composite was obtained by ion exchange method of copper ions into zeolites frameworks. lodine test, XRD, FTIR and autosorb IQ automated gas sorption analyzer were used to characterize the adsorbents. The mean concentrations of $\mathrm{Cd}, \mathrm{Cr}$, and $\mathrm{Pb}$ in untreated sample were $0.795,0.654$ and $0.7025 \mathrm{mg} / \mathrm{L}$ respectively. These concentrations decreased to $\mathrm{Cd}(0.005 \mathrm{mg} / \mathrm{L}), \mathrm{Cr}(0.052 \mathrm{mg} / \mathrm{L})$ and $\mathrm{Pb}$ (bellow detection limit, BDL) for sample treated with bare zeolite $X$ while a further decrease in concentration of $\mathrm{Cd}(0.005 \mathrm{mg} / \mathrm{L}), \mathrm{Cr}(\mathrm{BDL})$ and Pb $(\mathrm{BDL})$ was observed for the sample treated with copper-zeolite composite. Zeolite $\mathrm{X}$ and copper-modified zeolite $\mathrm{X}$ showed complete elimination of total coliforms after 90 and 50 min contact time respectively.

Conclusion: The results obtained in this study showed high antimicrobial disinfection and heavy metal removal efficiencies of the synthesized adsorbents. Furthermore, these sorbents are efficient in significantly reducing physical parameters such as electrical conductivity, turbidity, BOD and COD.
\end{abstract}

Keywords: Wastewater, Copper-doped zeolite X, Adsorption, Heavy metals, Disinfection, Akaki river

\section{Introduction}

Rapid population growth and the consequent increase in anthropogenic activities have resulted in high demand for scarce water resources, generation of large volumes of wastewater requiring treatment technologies capable of removing multiple pollutants [1]. Major pollutants of concern include pathogenic microorganisms and

\footnotetext{
*Correspondence: amare2122@yahoo.com; atminale2004@yahoo.com ${ }^{1}$ Department of Chemistry, College of Natural and Computational Science, Energy and Environment Research Center, Dilla University, 419, Dilla, Ethiopia

${ }^{2}$ Department of Chemistry, College of Science, Bahir Dar University, P.O. Box 79, Bahir Dar, Ethiopia

Full list of author information is available at the end of the article
}

persistent heavy metals (like $\mathrm{Pb}, \mathrm{Cr}$ and $\mathrm{Cd}$ ), which are harmful to humans when they exceed permissible limits. As per the World Health Organization's (WHO) guideline, the maximum permissible limits of these pollutants in drinking water are $0 \mathrm{CFU} / \mathrm{mL}$ for faecal coliforms, $0.003 \mathrm{mg} / \mathrm{L}$ for $\mathrm{Cd}, 0.01 \mathrm{mg} / \mathrm{L}$ for $\mathrm{Pb}$ and $0.05 \mathrm{mg} / \mathrm{L}$ for Cr [2-4].

Addis Ababa, the capital city of Ethiopia, has many rivers and tributaries. Among which, Akaki Rivers (Little Akakki and bigger Akaki rivers) are those rivers which receives polluted water from several tributaries such as Kebena, BancheYeketu, Kortame, Bulbula, LequSoramba, kotebe and Fincha rivers etc. [5]. These river tributaries are becoming an environmental concern in Addis Ababa 
city and its vicinity areas, where (more than $40 \%$ of large and medium scale manufacturing industries are located and some of these industries discharge their effluents to these rivers without being properly treated $[5,6]$. As a result, Akaki river is believed to be highly polluted chemically, physically and bacteriologically, and as a result the river water is unfit for domestic, industrial, commercial and agricultural uses [5]. Therefore, those industries discharging their effluents to this river and river tributaries require more treatment technologies that can handle multiple pollutants [7].

Among the various treatment technologies, ion exchange and adsorption are feasible and cost effective to remove heavy metals using an exchanger/sorbent with high selectivity for the target metal [8]. In the last few decades, sorbents for the treatment of heavy metals contamination have been investigated. Numerous waste biomass sources such as rice husk, saw dust, tea and coffee waste, orange peel peanut shells, activated carbon, dry tree leaves and barks, papaya seed, egg shell and coconut leaf powder were used as adsorbent for the removal of heavy metals from various waste water sources [9-12]. However, these adsorbents have several limitations such as stability, reusability and others.

An alternative to the natural products, low-cost zeolite sorbents, which have unique ion exchange and sorption properties, have been investigated as candidates for costeffective removal of heavy metals from waste solution. Synthetic, natural and modified zeolites have been tested $[1,8,13]$. However, the modified and synthetic zeolites were found to be advantageous in terms of purity, uniform pore size and better ion exchange abilities as compared to natural zeolites [8].

Regarding microbial disinfection, several physical and chemical methods (chlorination, UV treatment, treatment with ozone, membrane filtration etc.) have been reported. Although these techniques provide water of high microbiological quality, they have several limitations such as expensiveness, formation of byproducts, requirement of pre-treatment step, and/or being resisted by some microbials [14]. Thus, as an alternatives strategy, the application of metal nanoparticles for water disinfection and treatment had been reported by many researchers. The metallic nanoparticles are most promising for disinfection as they exhibit high anti bacterial properties due to their large surface area to volume ratio. Copper in the form of nanoparticle has good bactericidal activity [15]. Hence copper has been immobilized on different inorganic support materials for a wide range of antimicrobial applications including water and wastewater disinfection [15-18]. There is also a report showing the bactericide effect of the Mexican natural zeolites modified with silver ions in the treatment of wastewater [13].
However, there is no report showing the simultaneous heavy metal and microbial removal efficiency of unmodified and modified synthetic zeolite.

Thus, this study was aimed to demonstrate the simultaneous removal effect of copper doped and unmodified synthetic zeolite for decreasing the heavy metals, biological load and some physical parameters (BOD, COD, turbidity and electrical conductivity) in wastewater treatment processes.

\section{Methods/experimental \\ Chemicals and reagents}

All chemicals used were analytical grades. Two kilogram of Kaolin sample was collected from Hadiya zone Balesa district, Ethiopia. $\mathrm{CuSO}_{4}$ as precursor for loading copper, deionized water for washing the adsorbent, $\mathrm{HNO}_{3}$ and $\mathrm{NaOH}$ for $\mathrm{pH}$ adjustment, ascorbic acid as reductant were used in the experiment.

\section{Instruments and apparatus}

Inductively coupled plasma atomic emission spectrometry (ICP-AES) Perkin Elmer 4300 DV model from USA was used to quantify the mass of copper dissolved in the leach liquor after adsorption experiment. Flame atomic absorption spectroscopy (FAAS) equipped with deuterium background corrector and air-acetylene flame system was used to quantify the heavy metals before and after absorption; X-ray diffraction (XRD), Fouriertransform infrared radiation (FTIR) and autosorb IQ automated gas sorption analyzer were used to characterize the adsorbent; $\mathrm{pH}$ meter, turbidity meter (VSI-13N NEPHELOMETER), conductivity meter (1153 JENWAY) were used to measure physico-chemical parameters of the effluents.

\section{Waste water sampling and study area description}

The Akaki catchment is located in central Ethiopia along the western margin of the Main Ethiopian Rift. The catchment is geographically bounded between $8^{\circ} 46^{\prime}-9^{\circ} 14^{\prime} \mathrm{N}$ and $38^{\circ} 34^{\prime}-39^{\circ} 04^{\prime} \mathrm{E}$. Composite samples were collected in 2 weeks interval during September-October 2017 and analyzed for biochemical oxygen demand (BOD), chemical oxygen demand (COD), temperature, turbidity, conductivity, $\mathrm{pH}$ and total coliforms. The concentrations of the heavy metals, $\mathrm{Cd}, \mathrm{Pb}$ and $\mathrm{Cr}$ were determined using FAAS before and after treatment. The large particles from the effluent sample were removed through sedimentation and stored at $25{ }^{\circ} \mathrm{C}$ in a dark place in acidic medium $\mathrm{pH} 2$ using $1.0 \mathrm{M} \mathrm{HCl}$ solution.

\section{Digestion of waste water sample}

Waste water samples were digested with $\mathrm{HNO}_{3}$ and $\mathrm{HClO}_{4}$ in the ratio of 3:1. The samples were digested on 
a hot plate at a temperature of $93{ }^{\circ} \mathrm{C}$ for $2 \mathrm{~h}$ following a method reported by Idera et al. [19].

\section{Instrument calibration}

Calibration curves were prepared to determine the concentration of the metals in the untreated and treated effluent sample solution. The FAAS instrument was calibrated using four series of working standards $(0.1,0.5$, $1.0,1.5 \mathrm{mg} / \mathrm{L})$. For the three metals, a correlation coefficient of 0.9998 was obtained.

\section{Synthesis of zeolite and copper doped zeolite}

Zeolite X was synthesized following the method which was originally optimized in our research group. In brief, the kaolin was washed with distilled water several times to remove the impurities and dried in an open air for about a week. The dried kaolin sample was ground with mortar and pestle and then sieved with $0.25 \mathrm{~mm}$ mesh size sieve. Metakaolin was synthesized by calcinations of kaolin in muffle furnace at $900{ }^{\circ} \mathrm{C}$ for $2 \mathrm{~h}$. About $20 \mathrm{~g}$ of the synthesized metakaolin was treated with $15 \mathrm{~mL}$ of concentrated $\mathrm{HCl}$ and allowed to settle for $6 \mathrm{~h}$. The metakaolin suspension was added to $\mathrm{NaOH}$ solution to $250 \mathrm{~mL}$ borosilicate flask to form a gel, and shaken on an orbital shaker at $270 \mathrm{rpm}$ until equal distribution of $\mathrm{NaOH}$ solution was obtained. To develop the zeolite framework, the homogenized sample was allowed to crystallize at $50{ }^{\circ} \mathrm{C}$ for $24 \mathrm{~h}$ in water bath and then dried in the oven. The dried sample was washed with deionized water to bring the $\mathrm{pH} 9$, dried, powdered and crushed to uniform pore size. The copper doped zeolite was prepared by ion-exchange method. About $10 \mathrm{~g}$ of the synthesized zeolite $\mathrm{X}$ was treated with $0.1 \mathrm{M}$ of copper sulphate $\left(\mathrm{CuSO}_{4}\right)$ followed by treatment with $0.2 \mathrm{M}$ ascorbic acid. The resulting $\mathrm{Cu}-Z$ Zeolite was dried at $70{ }^{\circ} \mathrm{C}$ overnight, ground using mortar and pestle and characterized for adsorption experiment. Here after, for clarity, the synthesized zeolite and copper doped zeolites are named as $\mathrm{Z}$ and $\mathrm{CuZ}$.

\section{Characterization}

The prepared zeolite $\mathrm{X}$ and copper doped zeolite $\mathrm{X}$ were characterized by X-ray diffraction (XRD), Fouriertransform infrared radiation (FTIR), inductively coupled plasma atomic emission spectrometry (ICP-AES) and autosorb IQ automated gas sorption analyzer. X-ray diffraction (XRD) patterns were acquired with a D2 phaser XRD-300 W, with measurements taken using $\mathrm{Cu} \mathrm{Ka}$ radiation at $40 \mathrm{kV}$ and $100 \mathrm{~mA}$. The X-ray patterns was recorded a linear silicon strip 'Lynx Eye' detector from $10^{\circ}$ to $70^{\circ}$ at a scan rate of $0.1^{\circ} \mathrm{min}^{-1}$. An FT-IR spectrometer (model: Nicolet NEXUS-670) with transmission mode was used to obtain the FTIR spectra. Each sample in $\mathrm{KBr}$ was scanned (64 times) from 4000 to $400 \mathrm{~cm}^{-1}$ with a resolution of $4 \mathrm{~cm}^{-1}$. The copper content in the zeolite, copper modified zeolite and leach liquor samples was measured using ICP-AES Perkin Elmer 4300 DV model from USA. The specific surface area of the zeolite $\mathrm{X}$ and copper doped zeolite $\mathrm{X}$ were obtained from $\mathrm{N}_{2}$ adsorption/desorption data measured at $77.4 \mathrm{~K}$ using autosorb IQ automated gas sorption analyzer. The samples were degassed at $50^{\circ} \mathrm{C}$ for $3 \mathrm{~h}$ prior to $\mathrm{N}_{2}$ adsorption. The specific surface area of the sample was calculated by using the multiple-point Brunauer-Emmett-Teller (BET) method in the relative pressure range $(\mathrm{P} / \mathrm{Po})$ of $0.05-0.3$ [20].

The loading extent of copper into zeolite $\mathrm{X}$ was studied using ASTM D4607-94 method. Iodine number was calculated by investigating the adsorption of iodine from solution using $0.1 \mathrm{~N}$ standardized iodine solution and the titrant sodium thiosulfate $(0.1 \mathrm{~N})$. The milligrams of iodine adsorbed by $1.0 \mathrm{~g}$ of zeolite $\mathrm{X}$ when the iodine concentration of the filtrate is $0.02 \mathrm{~N}$ was calculated.

\section{Batch adsorption experiment}

Batch equilibrium experiments were carried out to find the optimum adsorbent dose, contact time and initial metal concentration. About 0.5-3.0 g of adsorbent (zeolite $\mathrm{X}$ and copper-doped zeolite $\mathrm{X}$ ) was added into synthetic solution of each metal and stirred for $4 \mathrm{~h}$ and then kept for $24 \mathrm{~h}$ until equilibrium could achieve and filtered. The experiment was carried out in duplicate. The optimum mass of adsorbent was obtained by plotting the percentage removal versus the mass of adsorbent. The effect of contact time in removal of $\mathrm{Cd}, \mathrm{Cr}$ and $\mathrm{Pd}$ using zeolite $\mathrm{X}$ and copper doped zeolite $\mathrm{X}$ is studied in a contact time range of 30 to $105 \mathrm{~min}$. Removal of metal ions was also carried at different initial concentration of metals $(1-25 \mathrm{mg} / \mathrm{L})$.

\section{Determination of $\mathrm{Cd}, \mathrm{Cr}$ and $\mathrm{Pb}$ in waste water before and after treatment with zeolite $X$ and copper doped zeolite $X$}

Following the optimized procedure, $2 \mathrm{~g}$ of bare zeolite $\mathrm{X}$ or copper doped zeolite $\mathrm{X}$ was added to $50 \mathrm{~mL}$ of the composite waste water containing the $\mathrm{Cd}(0.795 \mathrm{mg} / \mathrm{L})$, $\mathrm{Cr}(0.658 \mathrm{mg} / \mathrm{L})$ and $\mathrm{Pb}(0.696 \mathrm{mg} / \mathrm{L})$ metals (at $\mathrm{pH} 7.5)$. The solution was shaken for $60 \mathrm{~min}$, filtered using Whatman filter paper, acidified to $\mathrm{pH}<2$ and stored in refrigerated prior to AAS analysis.

$$
\% \text { metal removal efficiency }=\left[\left(\mathrm{C}_{\mathrm{i}}-\mathrm{C}_{\mathrm{f}}\right) / \mathrm{C}_{\mathrm{i}}\right] \times 100
$$

where $C_{i}$ and $C_{f}$ are the initial and final metal concentrations respectively. 


\section{Bacteriological analysis}

The adsorbent's microorganism removal efficiency was tested by taking $100 \mathrm{~mL}$ of the river water sample before and after treatment. The number of total coliform was counted by using a magnifying glass lens. Total coliform count of waste water samples were determined by plate count method using Methylene Blue Agar and coliform colonies were enumerated and expressed as total coliform $/ 100 \mathrm{~mL}$ of water samples.

\section{Turbidity reduction test}

Turbidity of the waste water sample was tested by using portable turbidity meter. Turbidity removal efficiency of the zeolite $\mathrm{X}$ and copper-zeolite $\mathrm{X}$ composite were evaluated and compared. Turbidity of the water samples was measured relative to the turbidity of distilled water having turbidity 2 NTU. The turbidity reduction was calculated by the following formula [21]. spiked samples were digested and analyzed in similar conditions. Thus, the efficiency of the optimized procedure was checked by spiking $1.0 \mathrm{~mL}$ of $100 \mathrm{mg} / \mathrm{L}$ of $\mathrm{Cr}, 12.5 \mathrm{mg} / \mathrm{L}$ of $\mathrm{Cd}$ and $50 \mathrm{mg} / \mathrm{L}$ of $\mathrm{Pb}$ into a $50 \mathrm{~mL}$ of river water sample. As shown in Table 1, the results of the percentage recovery for the studied metals in Akaki river sample lie within the acceptable range. Therefore, this verifies that the optimized digestion procedure was valid for the analysis.

\section{Copper loading into zeolite $X$}

Copper doped zeolite $\mathrm{X}$ was prepared by ion-exchange method. Iodine adsorption number is the most fundamental parameter used to identify pore size of most adsorbents. It is used to measure the activity level (higher degree indicates higher activation), often

$$
\text { Turbidity removal }(\%)=\frac{\text { turbidity of source waste water }- \text { turbidity of treated waste water }}{\text { turbidity of source waste water }} \times 100 \%
$$

\section{Dissolved oxygen, biochemical oxygen demand and chemical oxygen demand test}

Organic pollutants in wastewater in general consist of proteins, carbohydrates and fats and oils; at approximately 50, 40 and 10\%, respectively. Priority pollutants, surfactants, and emerging contaminants represent trace organic pollutants in wastewater. Dissolved oxygen (DO), biochemical oxygen demand (BOD) and chemical oxygen demand (COD) considered as the most practical indicators of water organic pollutants quality [22]. The treated and untreated wastewater samples were analyzed for DO, COD and BOD, according to standard methods for examination of water and wastewater [23].

\section{Conductivity and $\mathrm{pH}$ test}

Conductivity and $\mathrm{pH}$ of the source river water and the treated water through zeolite $\mathrm{X}$ and copper doped zeolite $\mathrm{X}$ were measured using conductivity meter and $\mathrm{pH}$ meter respectively.

\section{Results and discussion}

\section{Method of detection limit (MDL) and method validation}

Before quantifying the metals in the water samples, the method detection limit of the FAAS was evaluated by analyzing six blank samples. It was found that the method detection limit of $\mathrm{Pb}, \mathrm{Cd}$ and $\mathrm{Cr}$ was $0.07 \mathrm{mg} / \mathrm{L}$, $0.03 \mathrm{mg} / \mathrm{L}$ and $0.04 \mathrm{mg} / \mathrm{L}$ respectively. The efficiency of the digestion procedure and analytical method (FAAS) was checked by adding known concentration of each metal in waste water sample. The spiked and the non reported in $\mathrm{mg} / \mathrm{g}$ (with typical range of $500-1200 \mathrm{mg} / \mathrm{g}$ ) and the micropores content of the copper doped zeolite $\mathrm{X}$ (values $>0$ to $20 \AA$, or up to $2 \mathrm{~nm}$ ) by adsorption of iodine from solution. The loading extent of copper into zeolite $\mathrm{X}$ and their corresponding iodine number was shown in Table 2. Zeolite X doped with $6.3 \mathrm{~g}$ copper provided maximum iodine value $(641.7 \mathrm{mg} / \mathrm{g})$ indicating good adsorption capacity with high porosity and high surface area. Adsorption capacity of copper doped zeolite increases with increasing the amount of copper loaded from 0.63 to $6.3 \mathrm{~g}$. However, further increase in copper loading beyond $6.3 \mathrm{~g}$, the adsorption iodine value decreases, indicating the presence of less active sites for adsorption. Thus, based on the determined iodine value above and in Table 2, the optimum amount of copper loading into the zeolite framework was $6.3 \mathrm{~g}$. Therefore, we fully characterized both undoped zeolite $\mathrm{X}$ (i.e. just zeolite X) and copper doped zeolite X (zeolite $\mathrm{X}$ loaded with $6.3 \mathrm{~g}$ of copper).

$\begin{aligned} & \text { Table } 1 \text { Recovery test for the optimized } \\
& \text { for heavy metals analysis }\end{aligned}$
\begin{tabular}{lllll}
\hline Elements & $\begin{array}{l}\text { Conc. } \\
\text { in sample } \\
\text { (mg/L) }\end{array}$ & $\begin{array}{l}\text { Amount } \\
\text { added } \\
\text { (mg/L) }\end{array}$ & $\begin{array}{l}\text { Conc. in spiked } \\
\text { sample (mg/L) }\end{array}$ & Recovery (\%) \\
\hline $\mathrm{Pb}$ & 0.696 & 2.00 & 2.57 & 93.7 \\
$\mathrm{Cd}$ & 0.795 & 0.25 & 1.03 & 94.0 \\
$\mathrm{Cr}$ & 0.658 & 1.00 & 1.65 & 99.2 \\
\hline
\end{tabular}


Table 2 lodine value and mass of copper loaded in modified zeolite

\begin{tabular}{lll}
\hline Sample & Loaded copper $(\mathbf{g})$ & $\begin{array}{l}\text { lodine } \\
\text { value } \\
\text { (mg/g) }\end{array}$ \\
\hline 1 & 0.63 & 478.4 \\
2 & 6.3 & 641.7 \\
3 & 63 & 584.4 \\
4 & 126 & 552.9 \\
5 & 189 & 426.2 \\
\hline
\end{tabular}

\section{Crystallinity studies of adsorbent}

To investigate the crystal structure and phase transformation of the synthesized zeolite $\mathrm{X}$ and copper doped zeolite X, we carried out XRD measurements of the samples. Figure 1 shows XRD patterns of zeolite X and copper doped zeolite X. As clearly seen in Fig. 1a, a strong diffraction peaks located at 2 Theta values of 14.3, 22.4, $24.5,31.9,35.3$ and 43.5 are characteristics and matching well with the diffraction patterns of zeolite $\mathrm{X}$ peaks (JCPDS card number: 01-070-2168), indicating the profound crystalline nature of the prepared zeolite $\mathrm{X}$. The XRD patters of copper doped zeolite X, shown in Fig. 1b, revealed a slight shift in the peak positions to lower degree or higher d-spacing (e.g. peak at $2 \theta=29.4,32.7$ and 41.8) and appearance of new emerging peaks (e.g. at $2 \theta=41.8$ and 57.1) compared with XRD patterns of zeolite X (Fig. 1a). The weak intense peaks at $2 \theta=14.3$ was disappeared while the more intense peak at $2 \theta=24.5$ becomes broader after incorporation of copper into the zeolite X. A decrease in the intensities of some diffraction peaks can be also observed, but the XRD analysis of the copper doped zeolite $\mathrm{X}$ shows excellent crystalline nature. The overall finding from XRD pattern suggests the incorporation of copper into the zeolite $\mathrm{X}$ framework.

The surface area of the prepared zeolite $\mathrm{X}$ and copper doped zeolite $\mathrm{X}$ samples were investigated by measuring the nitrogen adsorption and desorption isotherms. Figure 2a shows the nitrogen adsorption-desorption isotherms of prepared zeolite $\mathrm{X}$ and copper doped zeolite $\mathrm{X}$ samples. The shape of the isotherms for both samples can be categorized to type $\mathrm{V}$ isotherm (i.e. based on IUPAC recommendation) with $\mathrm{H} 4$ hysteresis loop, indicating the existence of mesopores character of the samples. Another uptake appears at high relative pressure $(\mathrm{P} / \mathrm{P} 0>0.85)$ for both samples are attributed to the filling of macropores formed by the packing of aggregated particles [24]. The determined BET surface area of the zeolite $\mathrm{X}$ was found to be $460 \mathrm{~m}^{2} / \mathrm{g}$, which is comparable to that of literature reported before [25]. However, the BET surface area of zeolite X was decrease to $435 \mathrm{~m}^{2} / \mathrm{g}$ after copper loading (i.e. $\mathrm{S}_{\mathrm{BET}}$ for copper doped zeolite $\mathrm{X}$ sample), indicating the successful incorporation of copper into the zeolite $\mathrm{X}$ frameworks. The decreased in surface area is attributed to the fact that $\mathrm{Cu}$ are embedded in the pores of zeolite resulting partial blocking of the zeolite pore access by copper, leading to a reduction in total specific surface area. The textural properties of the samples are summarized in Table 3. Cu loading did not brought significant effect on pore volume compared with zeolite X. However, the effect of $\mathrm{Cu}$ loading is more pronounced in decreasing the micropore volume. That is, for zeolite $\mathrm{X}$ sample, the micropore volume represents $94 \%$ of pore volume, while the value drops to $81 \%$ for the copper doped zeolite $\mathrm{X}$ sample.

To determine the structural information of the prepared zeolite $\mathrm{X}$ and copper doped zeolite samples, we also carried out measurement of FT-IR spectra of the
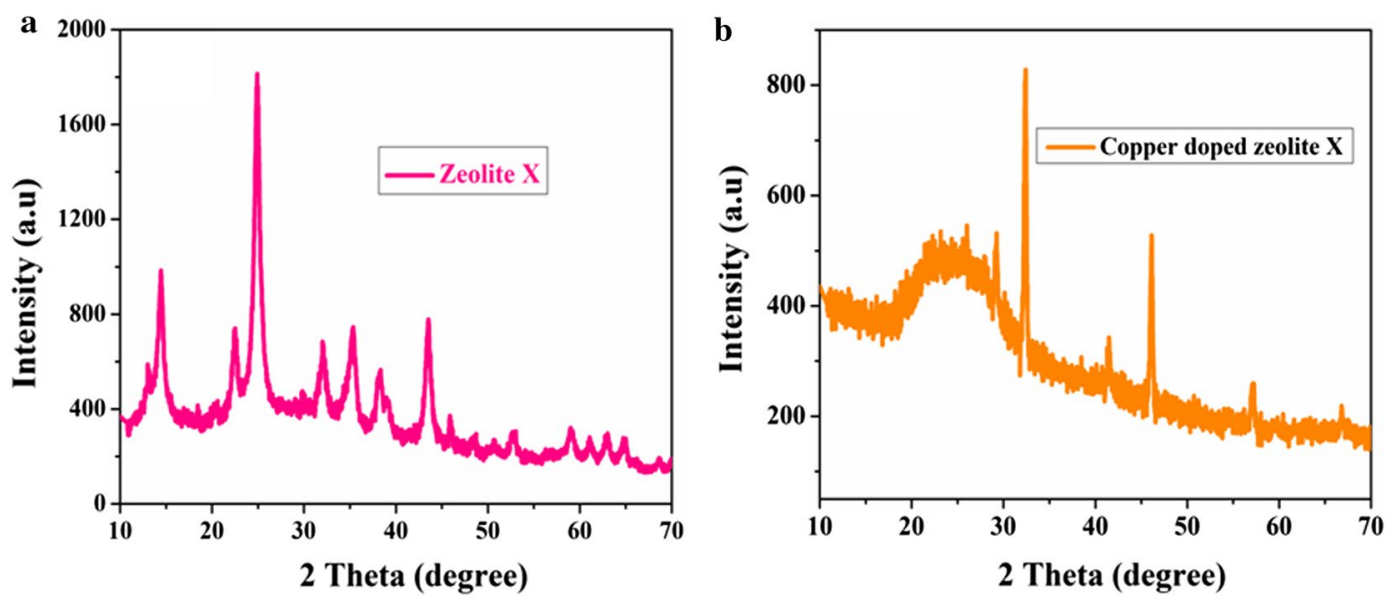

Fig. 1 XRD patterns of a zeolite $X$ and $\mathbf{b}$ copper doped zeolite $X$ 

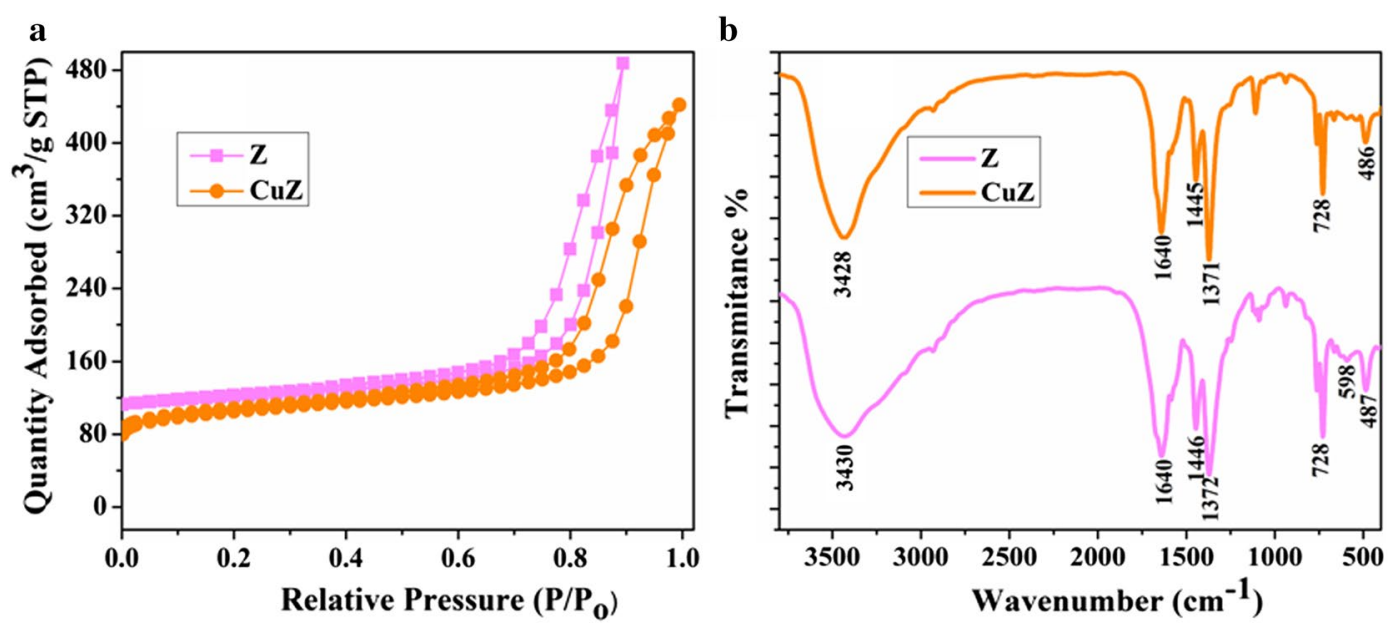

Fig. 2 a $\mathrm{N}_{2}$ adsorption-desorption isotherms and $\mathbf{b}$ FTIR spectra of as prepared zeolite $X$ and copper doped zeolite $X$

Table 3 Textural properties of zeolite $X$ and copper doped zeolite $X$ samples

\begin{tabular}{llll}
\hline Sample & $\mathrm{S}_{\mathrm{BET}}\left(\mathrm{m}^{\mathbf{2}} / \mathbf{g}\right)$ & $\begin{array}{l}\text { Pore volume } \\
\left(\mathbf{c m}^{\mathbf{3}} / \mathbf{g}\right)\end{array}$ & $\begin{array}{l}\text { Micropore } \\
\text { volume } \\
\left(\mathbf{c m}^{\mathbf{3}} / \mathbf{g}\right)\end{array}$ \\
\hline $\begin{array}{l}\text { Zeolite X } \\
\begin{array}{l}\text { Copper doped } \\
\text { zeolite X }\end{array}\end{array}$ & 460 & 0.214 & 0.201 \\
\hline
\end{tabular}

prepared zeolite $\mathrm{X}$ and copper doped zeolite $\mathrm{X}$ in the region from 400 to $4000 \mathrm{~cm}^{-1}$ in $\mathrm{KBr}$ using FTIR spectrometer. Figure $2 \mathrm{~b}$ displays the FTIR spectra of zeolite $\mathrm{X}$ and copper loaded zeolite X. As clearly seen in Fig. 2b, the IR spectra of zeolite $\mathrm{X}$ and copper doped zeolite $\mathrm{X}$ are quite similar to each other except that shifts of most vibrations to slightly lower frequency after $\mathrm{Cu}$ loading. The presence of a broad band at $3430 \mathrm{~cm}^{-1}$ in zeolite $\mathrm{X}$ sample can be ascribed to the $\mathrm{O}-\mathrm{H}$ stretching, and the band shifted towards a slightly lower frequency of $3428 \mathrm{~cm}^{-1}$ for copper doped zeolite $\mathrm{X}$ sample. This might be due to a decrease in $\mathrm{O}-\mathrm{H}$ bond strength. The bending vibrations of the $\mathrm{O}-\mathrm{H}$ at $1640 \mathrm{~cm}^{-1}$ showed insignificant change in position by both samples. The peaks located at 1446 and $1372 \mathrm{~cm}^{-1}$ are assigned to the O-NO stretching vibrations. The $\mathrm{T}-\mathrm{O}$ asymmetric stretching are observed at $938 \mathrm{~cm}^{-1}$ whilst the symmetric stretching of $\mathrm{T}-\mathrm{O}(\mathrm{T}=\mathrm{Si}$ or $\mathrm{Al})$ due to the internal vibrations of the zeolite $\mathrm{X}$ framework are observed at $728 \mathrm{~cm}^{-1}$. The absorption bands located at 598 and $487 \mathrm{~cm}^{-1}$ are assigned to the vibrations associated with the double six rings (D6R) that connect the sodalite cages and the internal vibrations due to the bending of the $\mathrm{T}-\mathrm{O}$ tetrahedral, respectively. We observed a slightly shift in vibrations to lower frequency by copper doped zeolite, indicating the successful loading $\mathrm{Cu}$ into zeolite frameworks. This is in good agreement with our XRD and BET results.

\section{Optimization parameters for removal of metals (using synthetic solution) Optimization of absorbent dose (zeolite $X$ and copper doped zeolite $X$ )}

The effects of zeolite $\mathrm{X}$ and copper doped zeolite $\mathrm{X}$ dosages on the removal of metal ion are illustrated in Fig. 3. The adsorbent dosage was varied from 0.5 to $3 \mathrm{~g} / 25 \mathrm{~mL}$ for both adsorbents. The concentration of $\mathrm{Pb}, \mathrm{Cd}$ and $\mathrm{Cr}$ before treatment were $0.696,0.795,0.658 \mathrm{mg} / \mathrm{L}$ respectively. At the same operating conditions (stirring speed, initial $\mathrm{pH}$ and temperature), the concentration of $\mathrm{Pb}, \mathrm{Cd}$ and $\mathrm{Cr}$ were decreased to $0.214,0.029$ and $0.063 \mathrm{mg} / \mathrm{L}$ using zeolite $\mathrm{X}$ treatment while to $\mathrm{BDL}$ (bellow detection limit), 0.012 and BDL mg/L using copper doped zeolite treatment. It is observed from Fig. 3, that the removal efficiency of adsorbents generally improved with increasing the amount of zeolite $\mathrm{X}$ and copper doped zeolite $\mathrm{X}$. This was as expected because the higher dose of adsorbent in the solution, the greater availability of exchangeable sites for the ions. At the same adsorbent dose, copper doped zeolite X has better removal efficiency for Pd, $\mathrm{Cd}$ and $\mathrm{Cr}$ metals (Fig. 3). In this finding, the optimum adsorbent dose of $\mathrm{Pb}, \mathrm{Cd}$ and $\mathrm{Cr}$ were $2 \mathrm{~g}, 1 \mathrm{~g}, 2 \mathrm{~g}$ for zeolite $\mathrm{X}$ and $2 \mathrm{~g}, 1.5 \mathrm{~g}$ and $1 \mathrm{~g}$ for copper doped zeolite respectively (Fig. 3). At optimum adsorbent dosage the percent removal efficiency for $\mathrm{Pd}, \mathrm{Cd}$ and $\mathrm{Cr}$ metals using zeolite $\mathrm{X}$ is $(69.5,96.4$ and $90.4 \%)$ and for copper doped zeolite $\mathrm{X}$ is (100, 98.5 and 100\%) respectively. As shown in Fig. 3a, at low dosage, zeolite and copper modified zeolite showed similar performance towards 

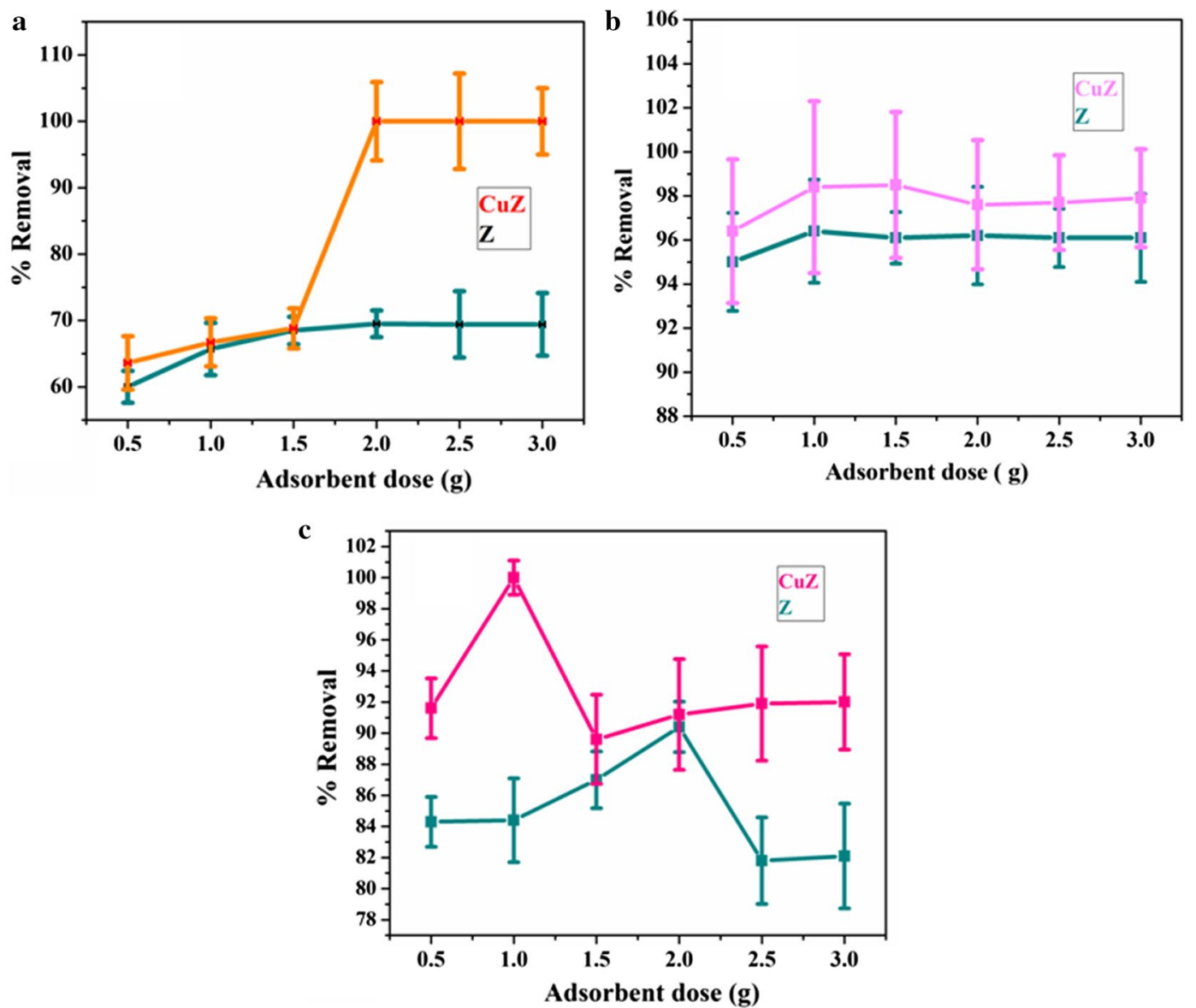

Fig. 3 Dose effect of zeolite $X$ and copper doped zeolite $X$ for removal of $\mathrm{Pb}(\mathbf{a}), \mathrm{Cd}(\mathbf{b})$ and $\mathrm{Cr}$ (c)

removal of lead. This might be due to scarcity of available enough active sites, further indicating copper modification did not bring significant change in performance at low dosage.

\section{Optimization of absorbent contact time}

The effect of contact time on the percentage removal of each metal was also studied in duplicate analysis by using optimum adsorbent dosage (zeolite $\mathrm{X}$ and copper doped zeolite $\mathrm{X})$. The applied time intervals were $30,45,60,75$, 90, and $105 \mathrm{~min}$. As shown in Fig. 4, increasing the contact time increases the percentage removal of each metal until the system reaches the adsorption equilibrium. From this study, it is found that the optimum contact time revealing maximum percentage removal of $\mathrm{Pd}, \mathrm{Cd}$ and $\mathrm{Cr}$ were 75, 105, $90 \mathrm{~min}$ and 45, 45, $60 \mathrm{~min}$ for zeolite $\mathrm{X}$ and copper doped zeolite respectively. In all the cases, copper doped zeolite $\mathrm{X}$ provided maximum percentage removal of $\mathrm{Pd}, \mathrm{Cd}$ and $\mathrm{Cr}(100,98.4$ and 100\%) in short period of time than bare zeolite X (69.7, 96.3 and 90.4\%).
This indicates, copper doped zeolite $\mathrm{X}$ had more active sites than bare zeolite $\mathrm{X}$.

\section{Effect of the initial metal ion concentration}

To investigate the effect of initial concentration on the removal efficiency of heavy metals, we also carried out intensive optimization experiments revealing the effect of initial metal concentration. To different $50 \mathrm{~mL}$ size Erlenmeyer's flask, $25 \mathrm{~mL}$ sample of 1, 5, 10, 15, 20 and $25 \mathrm{mg} / \mathrm{L}$ concentrations of $\mathrm{Pb}, \mathrm{Cd}$ and $\mathrm{Cr}$ were added. To each of the above metal concentration, optimum dose of zeolite (2 g, $1 \mathrm{~g}, 5 \mathrm{~g})$ and copper doped zeolite (2 g, $1.5 \mathrm{~g}$ and $1 \mathrm{~g}$ ) for $\mathrm{Pb}, \mathrm{Cd}$ and $\mathrm{Cr}$ were added, and the mixture were mechanically stirred for their optimum time. After filtration the concentration of $\mathrm{Pb}, \mathrm{Cd}$ and $\mathrm{Cr}$ were analyzed using atomic absorption spectroscopy. The effects of initial metal concentration on the \% retention of $\mathrm{Pb}$, $\mathrm{Cd}$ and $\mathrm{Cr}$ by zeolite $\mathrm{X}$ and copper doped zeolite $\mathrm{X}$ is shown in Fig. 5. As shown in Fig. 5, except for Cr, the percentage removal efficiency $\mathrm{Pb}$ and $\mathrm{Cd}$ increases with increasing metal concentration in the aqueous solutions, 

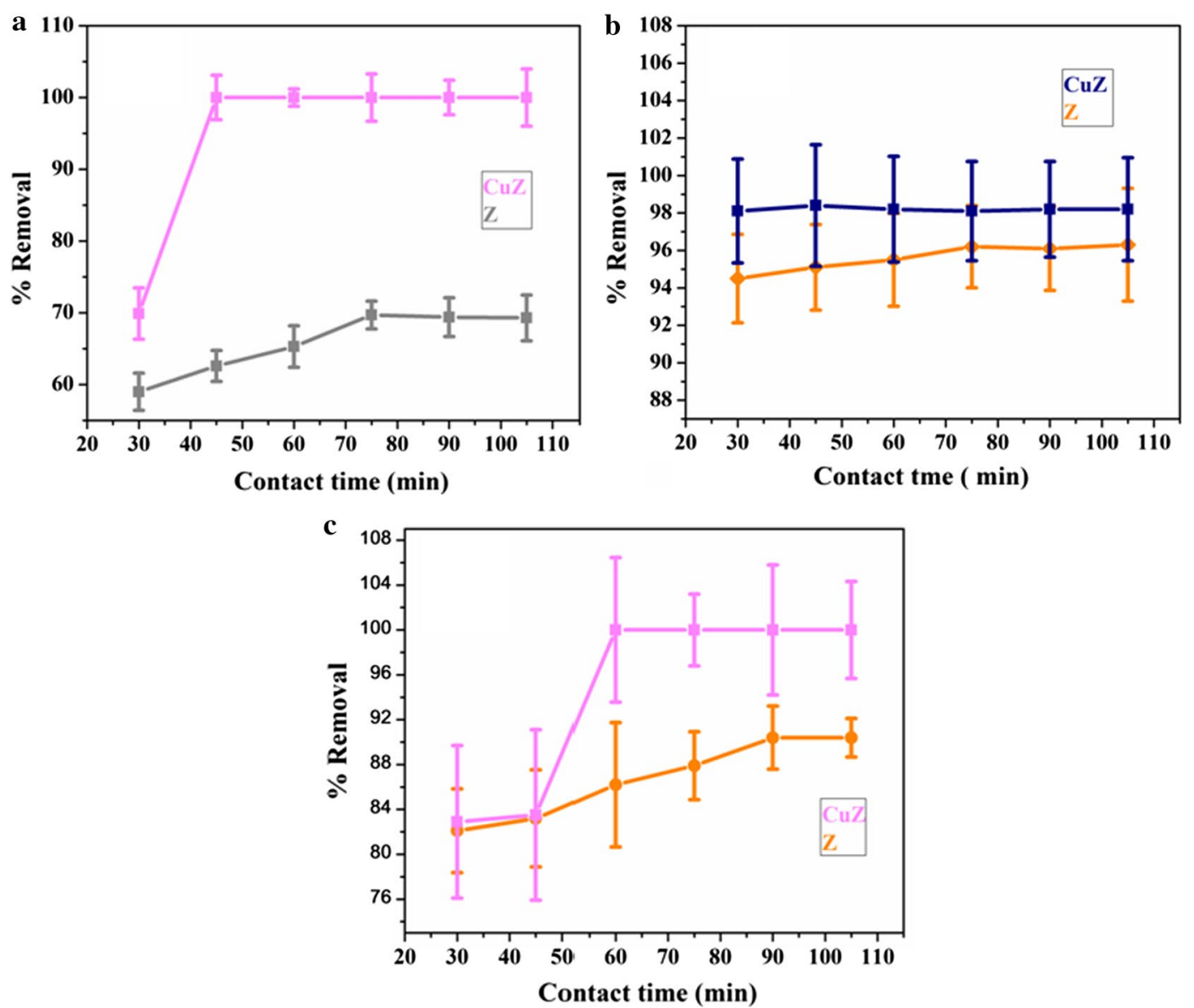

Fig. 4 Effect of contact time on the removal of $\mathrm{Pb}(\mathbf{a}), \mathrm{Cd}(\mathbf{b})$ and $\mathrm{Cr}$ (c) by zeolite $\mathrm{X}$ and copper doped zeolite $\mathrm{X}$ adsorbent

and reached the saturation point at higher initial concentrations. It is revealed that copper doped zeolite $\mathrm{x}$ exhibited efficient removal efficiency of $\mathrm{Cd}$ and $\mathrm{Cr}$ compared with undoped zeolite $\mathrm{x}$ while comparable response for $\mathrm{Pb}$ particularly at higher initial concentration. At the same initial concentration of each metal (i.e. $5 \mathrm{mg} / \mathrm{L}$ ), the maximum retention of the zeolite $\mathrm{X}$ and copper doped zeolite $\mathrm{X}$ were found to $93.7,95.9$ and $93.0 \%$ and $90.7,97.7$ and $100 \%$ for $\mathrm{Pb}, \mathrm{Cd}$ and $\mathrm{Cr}$ respectively.

The increase in adsorption or removal capabilities of the adsorbents with increasing in metal ions concentration could be explained by an acceleration of diffusion of metal ion into the adsorbents because of increase in concentration gradient with increase in initial metal ion concentration. As a result, the extent of each metal ion uptake by the adsorbents increases significantly with the increase of contact time. The slight decrease in the removal capacity or being remain constant after the saturation point of the adsorbents at higher initial metal ion concentration could be due to higher probability of collision between the adsorbent particle (zeolite $\mathrm{X}$ and copper doped zeolite X) and the metal ions; and decrease in the available active sites for adsorption due their saturation.

\section{Leaching test}

We conducted leaching tests to further evaluate the stability of the adsorbent. The mass of copper dissolved in the leach liquor after adsorption experiment was determined by elemental analysis in comparison with the original one in the zeolite framework. After $1 \mathrm{~h}$ adsorption experiment a very negligible $(0.78 \mathrm{ppb})$ amount of copper was detected in the leach liquor for the prepared copper doped zeolite powder (Table 4). A low amount of copper detection in the leach liquor after adsorption test confirms relatively a good adhesion of copper with the adsorbent material (i.e. zeolite).

\section{Application of zeolite $X$ and copper doped zeolite $X$} into adsorption experiment (real water samples from Akaki river)

Lead, cadmium and chromium removal efficiency of the prepared adsorbents, zeolite $\mathrm{X}$ and copper doped zeolite 

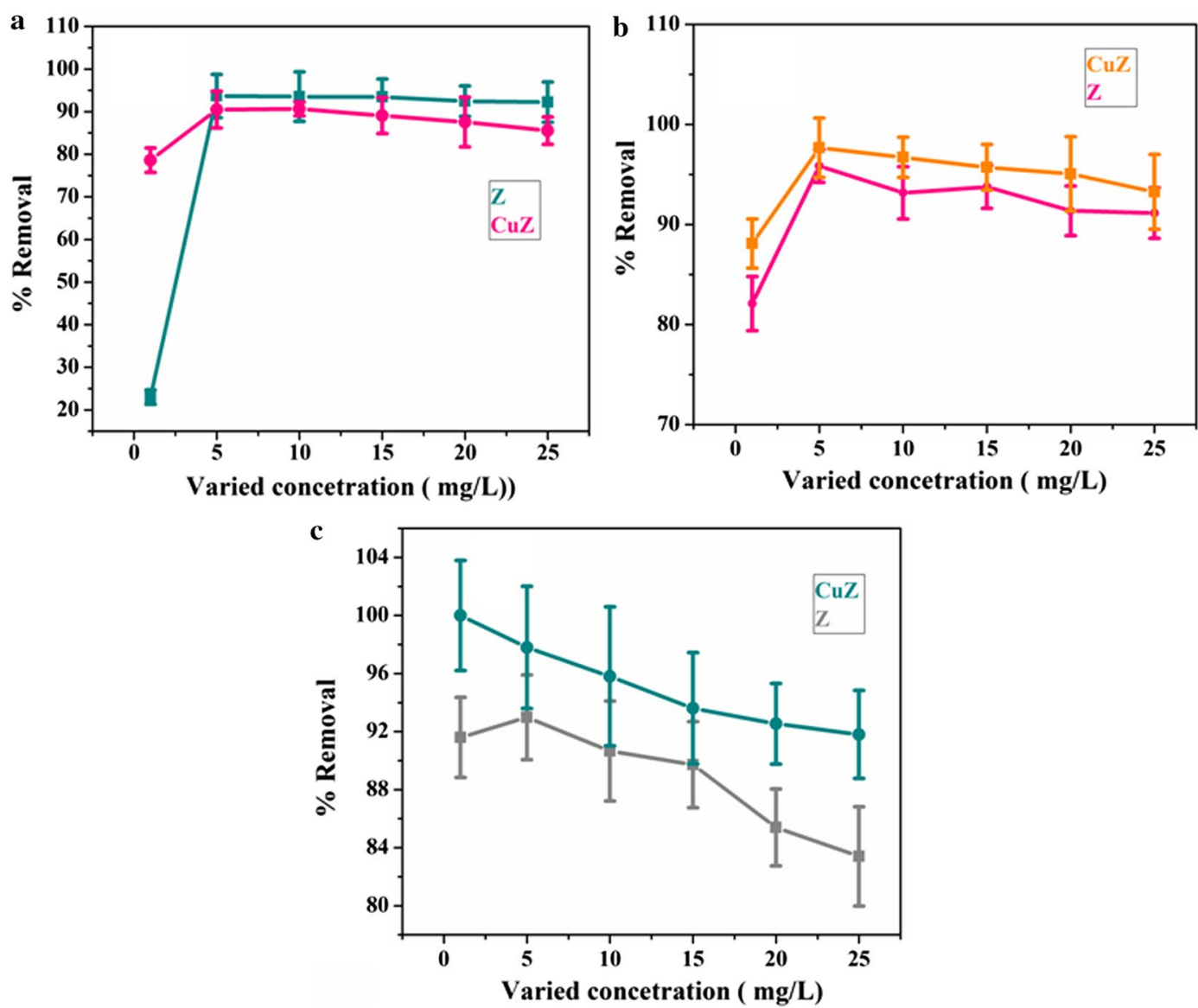

Fig. 5 Effect of initial metal concentration on the \% retention $\mathrm{Pb}(\mathbf{a}), \mathrm{Cd}(\mathbf{b})$ and $\mathrm{Cr}$ (c) by zeolite $\mathrm{X}$ and copper doped zeolite $\mathrm{X}$

\section{Table 4 ICP-OES test}

\begin{tabular}{ll}
\hline Sample & Concentration \\
\hline Initial raw material (i.e. zeolite) & $0.00 \mathrm{mg} / \mathrm{L}$ \\
$\begin{array}{l}\text { Copper doped zeolite before adsorption experiment } \\
\text { Copper doped zeolite leach liquor after adsorption } \\
\text { experiment }\end{array}$ & $0.78 \mathrm{mg} / \mathrm{L} / \mathrm{L}$ \\
\hline
\end{tabular}

$\mathrm{X}$, were tested on real water samples under optimized conditions. As it is clearly seen from Table 5, the concentrations of $\mathrm{Pb}, \mathrm{Cd}$ and $\mathrm{Cr}$ in the waste water samples before treatment were higher than the permissible level (0.696, 0.795 and $0.658 \mathrm{mg} / \mathrm{L}$ respectively for $\mathrm{Pb}, \mathrm{Cd}$ and $\mathrm{Cr}$ ). This concentration was reduced to BDL, 0.005 and $0.052 \mathrm{mg} / \mathrm{L}$ after the treatment with the adsorbent

Table $5 \mathrm{~Pb}, \mathrm{Cd}$ and $\mathrm{Cr}$ removal from the real water samples (Akaki river) using zeolite $\mathrm{X}$ and copper doped zeolite $\mathrm{X}$ at optimized conditions

\begin{tabular}{|c|c|c|c|c|c|}
\hline \multirow[t]{2}{*}{ Metal } & \multirow[t]{2}{*}{$\begin{array}{l}\text { Concentration } \\
\text { before treatment (mg/L) }\end{array}$} & \multicolumn{2}{|c|}{ After treatment with zeolite $X$} & \multicolumn{2}{|c|}{$\begin{array}{l}\text { After treatment with copper doped } \\
\text { zeolite X }\end{array}$} \\
\hline & & Concentration (mg/L) & Removal efficiency & Concentration (mg/L) & $\begin{array}{l}\text { Removal } \\
\text { efficiency }\end{array}$ \\
\hline $\mathrm{Pb}$ & 0.696 & $\mathrm{BDL}$ & 100 & $\mathrm{BDL}$ & 100 \\
\hline $\mathrm{Cd}$ & 0.795 & 0.005 & 99.37 & 0.005 & 99.37 \\
\hline $\mathrm{Cr}$ & 0.658 & 0.052 & 92 & $\mathrm{BDL}$ & 100 \\
\hline
\end{tabular}


Zeolite $\mathrm{X}$ and BDL, 0.005 and BDL for samples treated with copper doped zeolite X, respectively. Zeolite X and zeolite $\mathrm{X}$ doped with optimum copper loading have similar removal efficiency for $\mathrm{Pb}$ and $\mathrm{Cd}$. Whereas copper doped zeolite $\mathrm{X}$ has better removal efficiency of $\mathrm{Cr}$ than bare zeolite $\mathrm{X}$.

\section{Microbial removal efficiency}

As indicated in Table 6 and Fig. 6, the concentration of total coliform before treatment was $5.45 \times 10^{4} \mathrm{CFU} / 100 \mathrm{~mL}$ and after treatment in the filtrates runs was zero (CFU) per $100 \mathrm{~mL}$ of sample water. This was however expressed in terms of percentage reduction of total coliform removal denoted the microbial removal efficiency of $100 \%$ both for zeolite X and copper doped zeolite $\mathrm{X}$. This is most likely obtained due to high porosity of the adsorbent because of the high percentage of contact time. Zeolite X and copper-modified zeolite $\mathrm{X}$ enables completely eliminating microbes after 90 and 50 min contact time on average, demonstrating its effectiveness as a disinfectant respectively. Copper doped zeolite $\mathrm{X}$ with relatively high porosity and short contact time had good efficiency in removing microbial from bacterially contaminated water sources. When microorganism in contact with zeolite $\mathrm{X}$ and copper doped zeolite $\mathrm{X}$, there might be strong suffocation on their path due to the tortuosity of the path, and at the same time they compete for feeding which reduce the number of microbials after treatment.

\section{Properties of water samples before and after treatment}

Table 7 shows the physico-chemical parameters data of the water sample before and after treatment. It can be concluded that most of the parameters were changed after treatment towards the safe limit set by WHO. The reduction of COD and BOD might be the organic

Table 6 Microbial removal efficiency of the adsorbents

\begin{tabular}{lll}
\hline Code & Sample & Total coliform (CUF) \\
\hline A & Raw sample & $5.45 \times 10^{4}$ CFU/100 mL removal \\
B & Treated sample with zeolite X (at its optimum time) & 0 \\
C & Treated sample with copper doped zeolite X (at its optimum time) & 0 \\
\hline
\end{tabular}
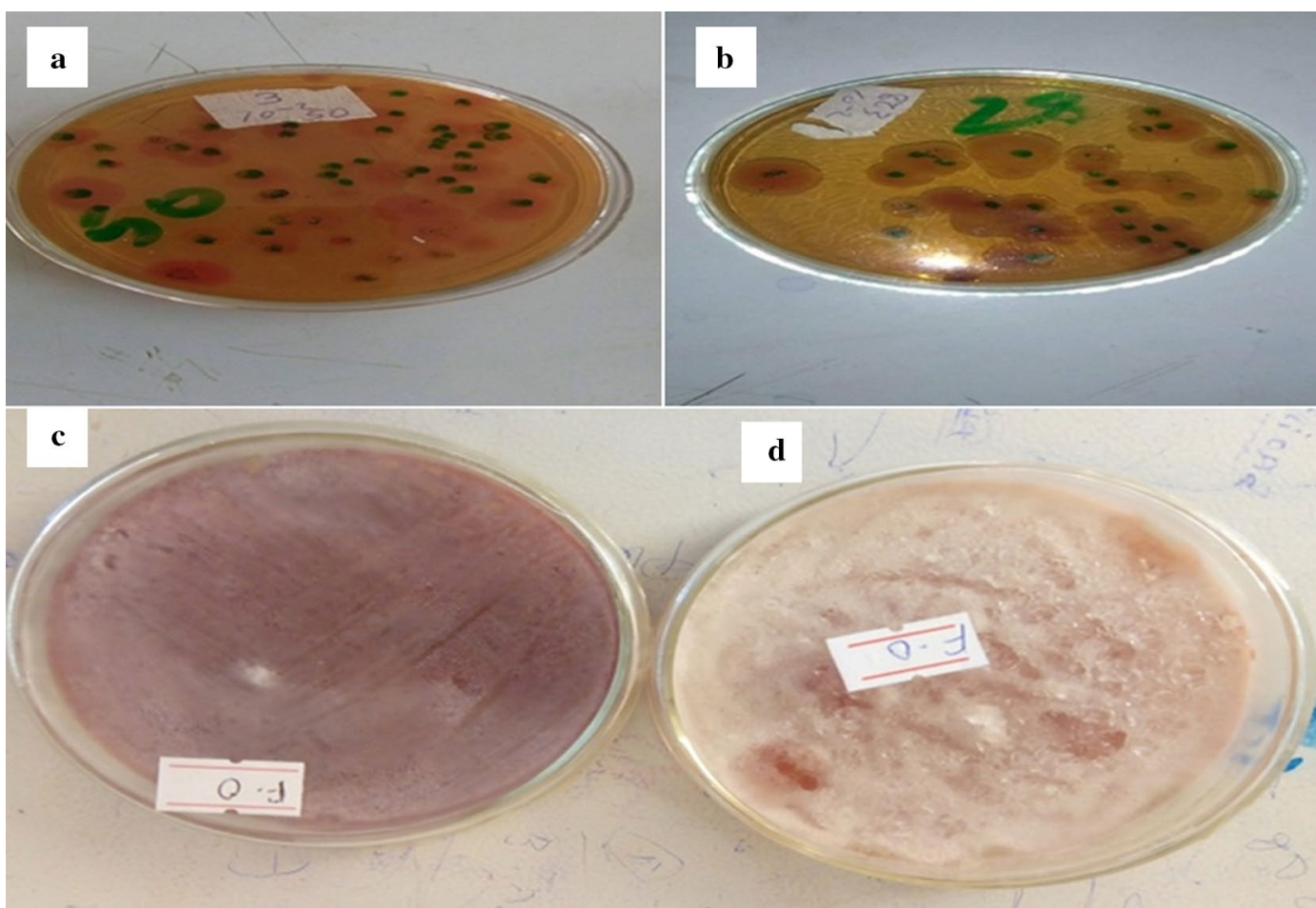

Fig. 6 Total coliform counting after incubation of 2 days ( $48 \mathrm{~h}$ ) of raw sample (a) and after treated with zeolite X (c); and before treated (b) and after treated with copper doped zeolite X (d) 
Table 7 Properties of raw water before treatment and after treatment with adsorbents

\begin{tabular}{llll}
\hline Parameter & Raw sample (A) & $\begin{array}{l}\text { Water sample treated with zeolite } \\
\text { (B) }\end{array}$ & $\begin{array}{l}\text { Water sample treated } \\
\text { with copper doped } \\
\text { zeolite (C) }\end{array}$ \\
\hline Temperature $\left({ }^{\circ} \mathrm{C}\right)$ & & 22.12 & 22.42 \\
$\mathrm{pH}$ & 22.45 & 7.5 & 7.5 \\
Conductivity $(\mu \mathrm{S} / \mathrm{cm})$ & 7.301 & 13.6 & 27.6 \\
Turbidity $(\mathrm{NTU})$ & 585 & 4.7 & 4.2 \\
DO (mg/L) & 78.6 & & 5.8 \\
Before incubation (average) & & 6.2 & 5.146 \\
After incubation (average) & 4.8 & 5.426 & 6.54 \\
$\mathrm{BOD}(\mathrm{mg} / \mathrm{L})$ & 2.658 & 7.74 & 7 \\
$\mathrm{COD}(\mathrm{mg} / \mathrm{L})$ & 22.14 & 6.8 & \\
\hline
\end{tabular}

compounds from the river's wastewater trapped in the pores of zeolite and copper-doped zeolite adsorbents. Hence, the oxygen needed to oxidize the organic substances becomes minimal and subsequently the COD and BOD content decreased significantly.

\section{Conclusions}

The use of copper-doped synthetic zeolite and bare synthetic zeolite were investigated for their combined heavy metal removal, antibacterial activity and reduction of physical parameters (BOD, COD, turbidity and electrical conductivity). The synthesized materials were characterized by X-ray diffraction (XRD), Fourier-transform infrared radiation (FTIR), autosorb IQ automated gas sorption analyzer and multiple-point Brunauer-Emmett-Teller (BET) method. The overall experimental results show that both bare zeolite $\mathrm{X}$ and the copper-doped synthetic zeolite $\mathrm{X}$ exhibited good antibacterial properties and heavy metal as well as physical parameters removal efficiency. However, the later material showed complete removal of the heavy metals under the same condition and with complete elimination of bacteria within 90 and $50 \mathrm{~min}$ of contact time respectively when bare zeolite $\mathrm{X}$ and the copperdoped synthetic zeolite $\mathrm{X}$ used. Hence, this adsorbent has very good potentials for simultaneous removal of microbes, organic maters and toxic metals removal from high-volume contaminated wastewaters. It also provides a substitute for the use of other expensive and less efficient materials as adsorbent.

\footnotetext{
Abbreviations

FTIR: Fourier-transform infrared spectroscopy; DO: dissolved oxygen; BOD: biochemical oxygen demand; COD: chemical oxygen demand; XRD: X-ray diffraction; Z: zeolite; CUZ: copper doped zeolites; BET: Brunauer-Emmett-Teller; MDL: method detection limit; BDL: bellow detection limit; ICP-OES: inductively coupled plasma optical emission spectrometry.
}

\section{Authors' contributions}

FTF performed the experiments; AAD, DFB and MA designed the study; FTF collected the data and drafted the manuscript; AAD and MA edited the manuscript. All authors read and approved the final manuscript.

\section{Author details \\ ${ }^{1}$ Department of Chemistry, College of Natural and Computational Science, Energy and Environment Research Center, Dilla University, 419, Dilla, Ethiopia. ${ }^{2}$ Department of Chemistry, College of Science, Bahir Dar University, P.O. Box 79, Bahir Dar, Ethiopia. ${ }^{3}$ Blue Nile Water Institute, Bahir Dar University, P.O. Box 79, Bahir Dar, Ethiopia.}

\section{Acknowledgements}

The authors are thankful to Dilla University and Bahir Dar University, Ethiopia for the financial support and provision of laboratory facilities.

\section{Competing interests}

The authors declare that they have no competing interests.

\section{Availability of data and materials}

The dataset used and/or analyzed during the current study are available from the corresponding author on reasonable request.

Funding

Not applicable.

\section{Publisher's Note}

Springer Nature remains neutral with regard to jurisdictional claims in published maps and institutional affiliations.

Received: 6 January 2019 Accepted: 20 March 2019

Published online: 01 April 2019

\section{References}

1. Tabassum N, Rafique U, Ashraf MA (2016) Metal doped green zeolites for waste water treatment: a sustainable remediation model. J Chem Soc Pak 38:424-437

2. WHO (2011) Guidelines for drinking-water quality, 4th edn. World Health Organization, Geneva

3. Lee CR, Cho I, Jeong B, Lee S (2013) Strategies to minimize antibiotic resistance. Int J Environ Res Public Health 10:4274-4305

4. Tripathi A, Ranjan MR (2015) Heavy metal removal from wastewater using low cost adsorbents. J Bioremediat Biodegrad 6:1-5

5. Yohannes H, Elias E (2017) Contamination of rivers and water reservoirs in and around Addis Ababa city and actions to combat It. Environ Pollut Climate Change 1:1-12 
6. Mulu A, Ayenew T, Berhe S (2013) Impact of slaughterhouses effluent on water quality of Modjo and Akaki river in Central Ethiopia. Int J Sci Res 6:2319-7064

7. Akhigbe L, Ouki S, Saroj D, Lim XM (2014) Silver-modified clinoptilolite for the removal of Escherichia coli and heavy metals from aqueous solutions. Environ Sci Poll Res 21:10940-10948

8. Yuna Z (2016) Review of the natural, modified, and synthetic zeolites for heavy metals removal from wastewater. Environ Eng Sci 33:443-454

9. Nguyen $\mathrm{TAH}, \mathrm{Ngo} \mathrm{HH}$, Guo WS, Zhang J, Liang S, Yue QY, Li Q, Nguyen TV (2013) Applicability of agricultural waste and by-products for adsorptive removal of heavy metals from wastewater. Bioresour Technol 148:574-585

10. Jayaweera HC, Siriwardane I, de Silva KN, de Silva RM (2018) Synthesis of multifunctional activated carbon nanocomposite comprising biocompatible flake nano hydroxyapatite and natural turmeric extract for the removal of bacteria and lead ions from aqueous solution. Chem Central J 12:1-14

11. Hegazi HA (2013) Removal of heavy metals from wastewater using agricultural and industrial wastes as adsorbents. HBRC J 9:276-282

12. Hussain AZ, Shariff KMM (2014) Removal of heavy metals from wastewater using low cost adsorbents. Arch Appl Sci Res 6:52-54

13. Rivera-Garza M, Olguın MT, Garcla-Sosa I, Alcántara D, Rodrıguez-Fuentes G (2000) Silver supported on natural Mexican zeolite as an antibacterial material. Microporous Mesoporous Mater 39:431-444

14. Milan Z, de Las Pozas C, Cruz M, Borja R, Sanchez E, llangovan K, Espinosa Y, Luna B (2001) The removal of bacteria by modified natural zeolites. J Environ Sci Health Part A 36:1073-1087

15. DeAlba-Montero I, Guajardo-Pacheco J, Morales-Sánchez E, AraujoMartínez R, Loredo-Becerra GM, Martínez-Castañón GA, Ruiz F, Compeán Jasso ME (2017) Antimicrobial properties of copper nanoparticles and amino acid chelated copper nanoparticles produced by using a soya extract. Bioinorg Chem Appl 2017:1-6

16. Rio L, Kusiak-Nejman E, Kiwi J, Bétrisey B, Pulgarin C, Trampuz A, Bizzini A (2012) Comparative methods to evaluate the bactericidal activity of copper-sputtered surfaces against methicillin-resistant Staphylococcus aureus. Appl Environ Microbiol 78:8176-8182
17. Harikumar PS, Aravind A (2016) Antibacterial activity of copper nanoparticles and copper nanocomposites against Escherichia coli bacteria. Int I Sci 5:83-90

18. JankauskaitL V, VitkauskienL A, Lazauskas A, Baltrusaitis J, ProsyLevas I, AndruleviLius M (2016) Bactericidal effect of graphene oxide/Cu/ Ag nanoderivatives against Escherichia coli, Pseudomonas aeruginosa, Klebsiella pneumoniae, Staphylococcus aureus and Methicillin-resistant Staphylococcus aureus. Int J Pharm 511:90-97

19. Idera F, Omotola O, Paul UJ, Adedayo A (2014) Evaluation of the effectiveness of different acid digestion on sediments. IOSR J App Chem 7:39-47

20. Ahmed IN, Yang XL, Dubale AA, Li RF, Ma YM, Wang LM, Hou GH, Guan RF, Xie MH (2018) Hydrolysis of cellulose using cellulase physically immobilized on highly stable zirconium based metal-organic frameworks. Bioresour Technol 270:377-382

21. Bulta AL, Micheal GAW (2019) Evaluation of the efficiency of ceramic filters for water treatment in Kambata Tabaro zone, southern Ethiopia. Environ Syst Res 8:1-15

22. Suleiman M, Mousa M, Hussein A (2015) Wastewater disinfection by synthesized copper oxide nanoparticles stabilized with surfactant. J Mater Environ Sci 6:1924-1937

23. APHA (1998) Standard methods for the examination of water and wastewater, 20th edn. American Public Health Association, American Water Works Association, Water Environment Federation, Washington, DC

24. Zhang X, Tang D, Zhang M, Yang R (2013) Synthesis of NaX zeolite: influence of crystallization time, temperature and batch molar ratio $\mathrm{SiO}_{2} /$ $\mathrm{Al}_{2} \mathrm{O}_{3}$ on the particulate properties of zeolite crystals. Powder Technol 235:322-328

25. Hammoudi H, Bendenia S, Marouf-Khelifa K, Marouf R, Schott J, Khelifa A (2008) Effect of the binary and ternary exchanges on crystallinity and textural properties of X zeolites. Microporous Mesoporous Mater 113:43-351
Ready to submit your research? Choose BMC and benefit from:

- fast, convenient online submission

- thorough peer review by experienced researchers in your field

- rapid publication on acceptance

- support for research data, including large and complex data types

- gold Open Access which fosters wider collaboration and increased citations

- maximum visibility for your research: over 100M website views per year

At BMC, research is always in progress.

Learn more biomedcentral.com/submissions 